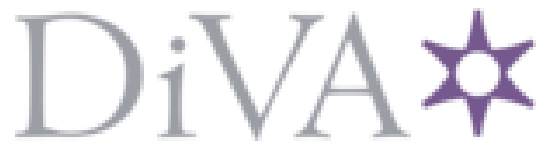

http://www.diva-portal.org

Preprint

This is the submitted version of a chapter published in The Palgrave Handbook of Ethnicity.

Citation for the original published chapter:

Elfversson, E. (2019)

Patterns and Drivers of Communal Conflict in Kenya

In: Ratuva, Steven (ed.), The Palgrave Handbook of Ethnicity Singapore: Palgrave Macmillan

https://doi.org/10.1007/978-981-13-0242-8_50-1

N.B. When citing this work, cite the original published chapter.

Permanent link to this version:

http://urn.kb.se/resolve?urn=urn:nbn:se:uu:diva-377688 


\title{
Patterns and drivers of communal conflict in Kenya
}

\author{
Author info \\ Emma Elfversson, Ph.D. \\ Researcher, Department of Peace and Conflict Research, Uppsala University, Uppsala, Sweden \\ emma.elfversson@pcr.uu.se
}

\begin{abstract}
This chapter analyzes patterns of communal conflict - i.e., violent conflicts between non-state groups which are organized based on communal identities - in Kenya. The politicized nature of ethnicity in Kenya, and the fact that both elections and land tenure are closely associated with ethnic identity, are highlighted as key factors explaining the prevalence of violent communal conflict. After discussing the main patterns of conflict since 1989, the chapter goes on to identify four main drivers of conflict: electoral politics, cattle raiding, local resources, and boundaries and local authority. The specific dynamics at play in different conflicts vary, and empirical examples illustrate how the precise way that different conflict drivers interact is different from case to case. The chapter also discusses different strategies by state and non-state actors to address and resolve communal conflicts, and how devolution - the decentralization of significant power to the local level under the 2010 constitution - has affected communal conflicts. As the discussion of devolution illustrates, a major point is that while communal conflicts in general should be seen against the background of a state and a political culture where ethnicity is strongly politicized, the impact of national-level political dynamics on communal conflicts will vary from case to case.
\end{abstract}

\section{Keywords or keyword phrases}

Communal conflict, Kenya, electoral violence, land conflict, pastoralist conflict, ethnic politics, conflict management, devolution

\section{Introduction}

Unlike most of its East African neighbours, Kenya has since independence not experienced large-scale rebellion or civil war. However, it has experienced a high number of more localized ethnic conflicts which at times have resulted in high death tolls (UCDP 2018; Kimenyi and Ndung'u 2005). Since 1989, by very conservative estimates, such conflicts have directly killed over 4000 Kenyan citizens. They have also caused the internal displacement of thousands of people and large-scale disruptions to local livelihoods. For example, in Tana River county in eastern Kenya two waves of violence- in 2001 and 2012 - between the Pokomo and the Orma and Wardei led to hundreds of deaths, the destruction of homes and villages, the displacement of thousands of people, and large-scale disruption of education and economic activities (Kirchner 2013; Martin 2012). The conflict is situated in a largely arid area, where the communities - who are mainly sedentary farmers, and pastoralists, respectively - are dependent on the river for their livelihoods. In Mount Elgon, which is located in western Kenya near 
the border with Uganda, conflict between local communities over the legitimate claim to local land and authority has pitted Sabaot against Luhya, and more recently Sabaot sub-groups against each other following controversy over government resettlement schemes. The latter wave of conflict gave rise to the militia Sabaot Land Defense Force (SLDF) which terrorized local citizens and was eventually quashed by a heavy-handed military intervention (Lynch 2011b).

This chapter deals specifically with this subcategory of ethnic violence which is termed communal conflicts, and where the government and state apparatus are not directly (but often indirectly) involved. There is a large body of research on how the Kenyan state has, under different regimes, engaged in violence and repression against its citizens (see for instance Hassan 2017; Boone 2011; Klopp and Zuern 2007; Murunga 2004). In contrast, in the case of communal conflict the primary conflict stands between two non-state groups which are organized based on communal identities, and which use lethal violence to gain control over some disputed and perceived indivisible resource, such as a piece of land or local political power. The fact that the primary parties in the conflict are non-state groups implies that neither side controls the state and armed forces. In turn, state actors and agencies may actively or passively support one side in the conflict, and/or intervene to end the violence and assist in promoting a negotiated solution.

A communal conflict is distinguished by the fact that mobilization, and the lines of confrontation, are based on communal identification, often ethnic identities. While rebel groups and state militias often organize along similar identity lines, the groups involved in communal conflicts are not formally organized in the same way as rebel groups - which have standing armies and a hierarchical command structure - and also tend to feature more sporadic outbursts of violence as compared to civil wars or conflicts between rivalling rebel groups. Communal identity is here understood as subjective group identification based on, for instance, a common history, culture or core values. Although identities are fluid and constructed and not inherently conflictual, under certain circumstances, they become more salient and can be activated for conflict mobilization (Klaus and Mitchell 2015; Svensson 2013). Because communal identity is socially constructed, it may change over time, and the dimension of identity that is emphasized for mobilization depends on the context. For instance, it may be ethnicity, religious affiliation, length of residence (i.e. "indigenes vs. settlers") or livelihood (Brosché and Elfversson 2012).

In Kenya, political developments during colonial rule and following independence have meant that ethnic identity is often activated and mobilized in conflict over resources and political power (Branch et al. 2010; Lynch 2011a; Oucho 2002; see also Mati in this volume). Importantly, land tenure has remained closely connected to communal identity, and political parties have largely formed and mobilized along ethnic lines (Elischer 2010; Kimenyi and Ndung'u 2005; Omolo 2002). This form of ethnic politics may contribute to different forms of organized violence, including civil war, secessionism and ethnic cleansing, but in Kenya the main violent manifestations have been in the form of communal conflict. Under colonial rule, the British favoured certain ethnic communities and deliberately sought to prevent the emergence of broad-based political movements (Branch et al. 2010). After independence in 1963, Jomo Kenyatta, the country's first president, took steps to centralize power in the hands of himself and a small elite, mainly from his own ethnic group, the Kikuyu. Kenyatta and his allies were also able to claim much of the best land around the country, a fact that still underlies bitter conflicts in the country. Subsequent political elites have continued to favour mainly their own ethnic community; land and resources have remained heavily concentrated in the hands of a few, and politics continues to be a very ethnic affair. Kenya has - depending on who you ask - 42 to 44 ethnic groups or "tribes", many of which comprise culturally distinct subgroups, and 
none of these groups makes up more than around $20 \%$ of the country's population. This has been noted as one potential explanation that ethnic politics has not resulted in a broad-based rebellion against the state (Kimenyi and Ndung'u 2005). Meanwhile, it has also meant that election politics have often been strongly characterized by a "game of numbers" whereby elite politicians enter short-lived alliances to create a sufficient electoral support (Lynch 2006; Elischer 2010).

This chapter begins by giving an overview of patterns of violent communal conflict in Kenya since 1989. It proceeds to discuss the main drivers of conflict, and illustrates these by discussing a few specific conflicts in more depth. Next, different strategies by state and non-state actors to address and resolve conflicts are discussed. Finally, the chapter discusses how devolution - the decentralization of significant power to the local level, introduced under Kenya's 2010 constitution - affects communal conflicts.

\section{Dynamics and drivers of communal conflict in Kenya}

Due to the politicized nature of ethnicity in Kenya, communal conflicts have tended to be particularly frequent and intense in connection to national elections. Figure 1 below illustrates overall patterns of violence since 1989, using data from the Uppsala Conflict Data Program (UCDP), which systematically collects information about different forms of organized violence, including communal conflict. The figure gives an overview of the number of conflicts each year that reached an intensity level of at least 25 deaths (left-hand axis/gray line), and the total number of fatalities resulting from these conflicts (right-hand axis/dotted line), over time. In addition to these high-intensity conflicts, there are many conflicts each year that turn violent but result in fewer casualties. In Figure 1, there are three notable peaks in terms of fatalities, and these coincide with the 1992, 1997 and 2007 elections. There are several reasons that election times often become particularly violent. First, politicians may call on ethnic identities and land-related grievances to mobilize support, and often whip up animosities against other communities (Boone 2011; Klaus and Mitchell 2015; Kurgat 2012). Furthermore, the outcome of elections at the local level often has implications for which community has access to local resources and patrimonial networks (Omotola 2010; Mieth 2012). This means that in addition to conflicts that are directly election-related (i.e., where violence is directed at affecting the election outcome (Höglund 2009)), conflicts revolving around other issues may also become intensified by the electoral dynamics. A peak in the number of active conflicts (as well as in total fatalities) can be seen in 2008 (in the aftermath of the 2007 elections): that year, there were nine conflicts that resulted in at least 25 deaths. It can also be noted that there were no conflicts of this intensity in 2002-2003, coinciding with the rise and electoral triumph of the National Alliance of Rainbow Coalition (NARC) which, at least at that point, brought together key representatives from all major ethnic groups in Kenya (Elischer 2010).

Figure 1. Active communal conflicts and fatalities in Kenya, 1989-2017

[Figure 1 here]

Based on UCDP Non-State Conflict Dataset v 18.1 (Sundberg et al. 2012)

Communal conflict has affected most regions of Kenya, but since 1989, the most intense conflicts have particularly been concentrated in the Rift Valley and in the Northeast, and on the coast. Figure 2 below 
illustrates the locations of major communal violence events - that is, incidents of lethal violence that form part of a violent communal conflict - since 1989. It should be noted that the figure only includes events in conflicts which at some point crossed the threshold of 25 deaths in a year. As the map illustrates, communal violence has also taken place in the major cities, including the capital Nairobi.

\section{Figure 2. Locations of major communal violence events, Kenya, 1989-2017}

[Figure 2 here]

Map made in QGIS, based on UCDP Georeferenced Events Dataset v 18.1 (Sundberg and Melander 2013).

On a general level, most communal conflicts in Kenya can be understood against the background of a political history that has rendered ethnic identity politically salient and important in relation to access to resources and opportunities. Other prominent underlying causes include socioeconomic inequality, marginalization, resource scarcity, and the weakening of customary institutions that used to manage conflicts between neighboring communities. However, there is also a lot of variation in terms of the specific issues that communities fight over, and different regions and localities face different combinations of factors contributing to conflict. For instance, in the Rift Valley many conflicts are related to longstanding grievances over land, and oftentimes overlapping land claims. Much of this violence has pitted groups with claims to indigeneity - notably, Kalenjin and Maasai - against ethnic groups who have more recently settled in the area, partly aided by political favoritism - notably Kikuyu and Kisii (Lynch 2011a; Anderson and Lochery 2008). Whereas active state orchestration has fueled communal violence in this region (cf. Boone 2011), in other areas conflict has erupted partly due to an absence of state governance and security provision. In the North Rift and Northeast Kenya, poor security provision in conjunction with porous borders and conflict in neighboring states have created a security vacuum wherein conflicts relating to cattle raids and territorial control have escalated to high levels (Mkutu 2008; Kumssa et al. 2009; Eaton 2012). Table 1 below presents an overview of all communal conflicts in Kenya that have been recorded by the UCDP since 1989. Again, it should be noted that the figures are conservative, and that the table does not capture the totality of intercommunal violence in Kenya but only the most intense conflicts.

Table 1. List of communal conflicts in Kenya, 1989-2017

\begin{tabular}{|l|l|l|l|}
\hline Communities & Main locations of violence & $\begin{array}{l}\text { Active years (with at } \\
\text { least 25 fatalities) }\end{array}$ & $\begin{array}{l}\text { Estimated total } \\
\text { deaths }\end{array}$ \\
\hline $\begin{array}{l}\text { Dassanetch - Nyangatom, } \\
\text { Toposa }\end{array}$ & North Rift & 1989 & 60 \\
\hline Kalenjin - Kikuyu & Rift Valley, Nyanza & $1992-1994,1998,2008$ & 327 \\
\hline Kalenjin - Luhya & Uasin Gishu, Bungoma & $1992-1993$ & 96 \\
\hline Kalenjin - Kisii, Luo & Rift Valley, Nyanza & 1992 & 40 \\
\hline Kikuyu - Maasai & Nakuru, Narok & 1993 & 102 \\
\hline Nyangatom - Turkana & $\begin{array}{l}\text { Turkana; South Omo } \\
\text { (Ethiopia) }\end{array}$ & 1993 & 246 \\
\hline Pokot - Turkana & $\begin{array}{l}\text { Turkana, West Pokot, } \\
\text { Baringo }\end{array}$ & $\begin{array}{l}1995,1999,2005-2006, \\
2008,2010,2013-2015\end{array}$ & 630 \\
\hline Pokot, Samburu - Turkana & Samburu & 1996 & 51 \\
\hline Samburu - Turkana & Samburu, Laikipia, Isiolo & 1996,2015 & 211 \\
\hline Samburu - Somali & Isiolo & 1996 & 49 \\
\hline
\end{tabular}




\begin{tabular}{|c|c|c|c|}
\hline Dassanetch - Gabra & $\begin{array}{l}\text { Marsabit; South Omo } \\
\text { (Ethiopia) }\end{array}$ & 1997 & 112 \\
\hline Kisii - Maasai & Trans Mara, Kisii & 1997 & 77 \\
\hline Dassanetch - Turkana & $\begin{array}{l}\text { Turkana, South Omo } \\
\text { (Ethiopia) }\end{array}$ & $\begin{array}{l}\text { 1997, 2000, 2005, 2009, } \\
2011\end{array}$ & 413 \\
\hline Nandi-Pokot & Trans Nzoia & 1998 & 35 \\
\hline Borana - Degodia & $\begin{array}{l}\text { Wajir; Somali state } \\
\text { (Ethiopia) }\end{array}$ & 1998 & 357 \\
\hline Jie - Turkana & Turkana; Jie (Uganda) & 1999,2008 & 101 \\
\hline Ajuran-Garre & Wajir, Moyale & 2000 & 78 \\
\hline Borana - Samburu & Isiolo & 2001 & 70 \\
\hline Marakwet-Pokot & Kerio Valley & 2001,2016 & 115 \\
\hline Orma, Wardei - Pokomo & Tana Delta & 2001 & 66 \\
\hline $\begin{array}{l}\text { Rer Ahmad - Hawarsame Rer } \\
\text { Hasan \& Habar Ya'qub }\end{array}$ & $\begin{array}{l}\text { Mandera; Belet Hawa } \\
\text { (Somalia) }\end{array}$ & 2004 & 69 \\
\hline Borana - Gabra & $\begin{array}{l}\text { Marsabit, Moyale; } \\
\text { Oromiya (Ethiopia) }\end{array}$ & 2005-2007, 2012 & 244 \\
\hline Garre - Murule & Mandera & 2005,2008 & 94 \\
\hline Nyangatom, Toposa - Turkana & Turkana & 2006 & 58 \\
\hline Pokot - Samburu & Samburu, Laikipia & 2006, 2009 & 76 \\
\hline Kalenjin - Kisii & Rift Valley & 2008 & 81 \\
\hline Kikuyu - Luo & Nairobi, Kisumu, Nakuru & 2008 & 61 \\
\hline Toposa - Turkana & Turkana; Equatoria (Sudan) & 2008. 2011 & 339 \\
\hline Borana - Turkana & Isiolo & 2011 & 31 \\
\hline Orma - Pokomo & Tana Delta & 2012 & 194 \\
\hline Degodia - Garre & Mandera, Wajir & $2012-2014$ & 216 \\
\hline Borana - Burji, Gabra & Moyale & 2013 & 55 \\
\hline
\end{tabular}

Based on UCDP Non-State Conflict Dataset v 18.1 (Sundberg et al. 2012) and UCDP Georeferenced Events Dataset v 18.1 (Sundberg and Melander 2013)

Given the different underlying and proximate causes of communal conflicts, they are fought over different issues, which in turn affects the type of strategies needed to manage and resolve them. Broadly, four main drivers of communal conflict can be observed in Kenya: electoral politics, cattle raiding, local resources, and boundaries and local authority. Oftentimes, several different drivers overlap; for instance, pastoralist conflicts often feature cattle raiding but also revolve around natural resources and local boundaries. In turn, while these drivers - as well as the overall political dimension emphasized above - often overlap, there is variation in which drivers coexist and how. Consequently, the precise dynamics in each case of communal conflict are distinct, and require locally well-anchored solutions.

\section{Electoral politics}

Many of Kenya's communal conflicts have been directly related to national and local elections. In particular, election-related communal violence became prominent under President Daniel arap Moi. Ascending to power after Kenyatta's death, Moi, who belongs to the Kalenjin community, continued to centralize power and turned Kenya into an authoritarian and corrupt one-party state. In the 1990s, Moi was under intense international and domestic pressure to liberalize and democratize the country, and opposition movements became stronger (Murunga and Nasong'o 2007). Moi tried to prevent these developments by fueling ethnic violence, both as a way to repress the opposition and to underline his claim that that democracy would plunge Kenya into ethnic civil war (Klopp 2001). Around 
the first multiparty elections, held in 1992, there were clashes mainly in the Rift Vally between Kalenjin and Maasai militias and other politically relevant ethnic groups - Kikuyu, Kisii, Luo and Luhya. Another wave of election-related communal violence followed in connection to the 1997 elections, this time also including clashes between "indigenous" groups and "newcomers" on the Coast (Kimenyi and Ndung'u 2005).

The election-related communal conflicts in the 1990 s were fueled by a political history and rhetoric that created a perception of ethnic voting as the way to ensure a stake in national and local resources, and more directly by political agents orchestrating ethnic violence (Kimenyi and Ndung'u 2005; Klopp 2001; Elischer 2010; Omolo 2002). For instance, Moi and his allies convinced the Kalenjin community - which is in turn made up by a number of culturally distinct subgroups with varying interests in relation to the then-ruling elite - that an opposition victory would threaten Kalenjin interests including access to land, and would lead to domination by other ethnic communities. In this context, politicians manipulated grievances related to land which can be traced back to colonial times and to perceived unjust land allocations under Kenyatta, and calls for majimboism - strengthened regionalism, commonly understood to correlate with ethnic "homelands" - were commonly heard at political rallies in the Rift Valley (Lynch 2011a).

Large-scale election-related communal violence also broke out in the aftermath of the 2007 elections. At this point, the presidential race stood between incumbent Mwai Kibaki (a Kikuyu) and opposition leader Raila Odinga (a Luo). Again, the Rift Valley was one of the main arenas of violence, but there were also intense clashes in Nairobi and sporadic violence in Western Kenya and on the Coast. The violence was preceded by rumours of electoral malpractices, and when the election results were announced on 29 December - with a victory for the incumbent - opposition supporters around the country believed the results were fraudulent and that they had been cheated of "their turn to eat" (a phrase referring to the notion that only those in power get a share of the country's resources). Importantly, the Luo are one of Kenya's largest ethnic groups but have largely been excluded from the top echelons of power (de Smedt 2009; Lynch 2006). At the same time, many Kalenjin in the Rift Valley hoped that an opposition victory would decrease the influence of the Kikuyu in their region and that their access to land would increase (Anderson and Lochery 2008).

When the results from the election started to circle, Kalenjin and Luo militias in Rift Valley and western Kenya started to attack Kikuyu, seeking to drive them away from local areas and to take over land and businesses by force. Kikuyu groups in turn also organized themselves and fought back. These patterns were also seen in the informal settlements in Nairobi, prominently Kibera, which was Odinga's main political base and where Luo "tenants" turned against "landlords" from Kikuyu and other communities (for an in-depth account of the dynamics in Kibera, see de Smedt 2009). Both in the Rift Valley and in Nairobi, ethnic militias involved in the violence were paid and organized by different local politicians as well as different local businessmen (Waki 2008). Waves of violence continued for several weeks, ending only after a national-level power sharing arrangement was negotiated under high international pressure, whereby Odinga was given a post as prime minister and a process to reform the constitution was set in motion (cf. Mati 2013).

\section{Cattle raiding}

Some of the most violent communal conflicts in Kenya in recent decades have involved pastoralist communities that have attacked each other and raided cattle. Such conflicts have a long history and are rooted in pastoralist customs, where cattle raids have filled a dual function as a rite of passage as 
well as restocking herds or acquiring bridewealth. However, a focus only on the cattle-raiding dynamics underplays the political dimension of these conflicts, and a portrayal of violence as "tribal" and "traditional" has at times been an active strategy by authorities to downplay its importance and its connection to local and national politics (Greiner 2013; Okumu et al. 2017; Schilling et al. 2015). By implying that pastoralist livelihoods are inherently violent and conflictual, state authorities can simultaneously downplay their own failure to prevent or address these conflicts, and further underline the general marginalization and lack of accommodation of groups whose livelihoods do not easily fall in line with national agendas for development. Generally speaking, the development of the Kenyan state has weakened customary pastoralist institutions and decreased the availability of pastoral land, but has to a very limited degree provided strong state institutions and alternative livelihood opportunities.

When taking a historical view of these conflicts, there is broad consensus that cattle raids have become increasingly violent over the past half century, and that the high level of armament among the involved communities have generated an arms race dynamic that further compounds insecurity (Mkutu 2008; Okumu et al. 2017). These conflicts take place in areas where the state's presence is very limited and security poorly enforced, leading to self-defensive armament and pre-emptive violence; these dynamics in turn have been fueled by the inflow of small arms and light weapons (SALW) from war-affected neighboring countries (Mkutu 2008; Eaton 2012). A further factor contributing to intensified violence is the fact that raiding has become "commercialized"; whereas cattle were traditionally only raided for family or community needs, they are now quickly transported out of the area and sold on the black market. Finally, while raiding for a long time was largely detached from conflicts over land and boundaries - a function of the imposition of fixed local borders during colonial rule - more recently these conflicts have also gained a territorial dimension, and as such also become more politicized, as local political elites may use the violence to seek to renegotiate administrative boundaries (Greiner 2013).

One notable example where cattle raiding has played a major part is the conflict between the Pokot and Turkana, two communities that inhabit neighboring areas in northwest Kenya (the Pokot, who are a Kalenjin subgroup, mainly inhabit Baringo and West Pokot Counties, and the Turkana dominate Turkana County). Both are pastoralist, semi-nomadic groups and move around with their cattle across vast arid lands, which have for long been at the periphery of the Kenyan state-building project and largely neglected in terms of development and infrastructure. Security provision is sparse and largely made up of the paramilitary General Service Unit (GSU) and police reservists or "home guards" (Mkutu 2008). The relative weakness and inefficiency of state security provision has contributed to create a local security dilemma and concomitant arms race, whereby the groups have an incentive to arm themselves for defensive purposes and at times to make preemptive attacks when the enemy is relatively weak. At times, the government has sought to disarm raiders in order to decrease violence, but when such campaigns have been conducted in an uneven fashion it has instead contributed to more violence by upsetting the local power balance (Lind 2018).

The Pokot-Turkana conflict has experienced violent and peaceful phases over a very long time, with the most recent wave of conflict beginning in the mid-1990s. At that point, the conflict gained a territorial dimension as the Turkana tried to occupy a piece of territory belonging to the Pokot (Greiner 2013). Subsequent raids have at times laid siege to villages or been aimed at capturing water holes, in addition to cattle raiding. Since 1995, violent clashes between the Pokot and Turkana have been recurring (see also Table 1 above) and have, by conservative estimates, caused more than 600 deaths. Both sides have heavily armed and well-organized militias, and large-scale raids often involve several hundred raiders most of whom are armed with AK47s or similar weapons. The level of armament is 
evidenced by the fact that the groups involved have also at times overpowered security forces sent to the region to halt the violence. In one highly publicized event, more than 20 police officers were ambushed and killed by Pokot raiders in Kapedo (on the border between Turkana and West Pokot) in November 2014, prompting President Kenyatta to deploy the military in the region (Lind 2018).

The conflict has intertwined with politics in several ways, further fueling the violence. Firstly, as in other communal conflicts in Kenya, violent displacement and the renegotiation of boundaries can affect electoral outcomes. More directly, political elites have benefited financially from the raiding "industry", and have in turn allegedly provided weapons to raiders from their community (Greiner 2013; Okumu et al. 2017). Border revisions by the central state have further fueled tensions; for instance, ahead of the 2013 elections local borders were redrawn so that the aforementioned Kapedo was "moved" from Turkana to Baringo County. The conflict gained a further dimension, adding to its intensity and complexity, as oil was discovered in Turkana in 2012. This has increased the value of the land, and has further heightened the local political stakes (Schilling et al. 2015; Greiner 2013). It also led to the entry of new actors - notably, the Anglo-Irish oil company Tullow Oil - in the region, ostensibly representing a promise for more local development and improved infrastructure but so far mainly serving to underline the marginalized nature of pastoralist livelihoods in relation to the Kenyan state. For instance, while many hoped that oil exploration and extraction would create much-needed local jobs and development, few locals have been hired by Tullow and when they have, the question of who gets hired or not has been manipulated by local politicians appealing to ethnic support bases (Lind 2018).

\section{Local resources}

As the discussion of the Pokot-Turkana conflict illustrates, one prominent driver of communal conflict relates to the control over, or access to, local natural resources such as grazing land or water. Oftentimes this conflict driver is connected to group livelihoods - such as competition over the use of land between two pastoralist communities, or between sedentary farmers and nomadic herders. This form of conflicts, which revolve around scarce natural resources, are often understood in relation to a broader context of natural degradation and climate change. They are also often fueled by unclear or overlapping rights and tenure provision. For instance, resource conflict in the Kajiado district in southern Kenya has been described as relating to population growth, changes to land tenure regulations, and international and national policies incentivizing changes in land use (Campbell et al. 2000). However, while a shrinking resource base and unclear rules about access may contribute to conflict, it is usually not enough for conflict to escalate into large-scale violence (Brosché 2014; Adano et al. 2012); to understand patterns of violence, local and national political dynamics must also be taken into account.

One example where local resources are at the heart of the conflict is found in the Tana Delta in the coastal region. Here there has been repeated violent conflict over resources between the Pokomo, who to a large degree pursue sedentary farming livelihood, and the pastoralist communities Orma and Wardei. Both sides depend on the river Tana for their livelihoods - the farmers grow their crops along the river, and the pastoralists move in with their animals during dry spells so they can drink from the river (Martin 2012). When violent conflict has erupted, it has often been triggered by incidents where cattle have destroyed farms, or where farmers have denied pastoralists access to the river. The communities have different traditions concerning communal and private land tenure, and have taken different positions in relation to irrigation projects and other state policies affecting land use. In 2001, a proposed land adjudication program increased tensions between the communities. The pastoralists 
interpreted the program as potentially excluding them from access to the river. These tensions coincided with the fact that a drought in 2000-2001 had caused the pastoralist communities to move closer to the river, increasing the pressure on local resources. In this context, clashes between the communities took place on several occasions during 2001, resulting in over 100 deaths (Kagwanja 2003; Martin 2012).

While differences in livelihood, land tenure systems and culture are often emphasized in analyses of the conflict, it is also clear that escalations and de-escalations have been driven by political dynamics. While the central government has arguably not been directly involved in the same way as in electionrelated conflicts in Rift valley, both sides in the Tana Delta conflict have at times perceived that the government was biased against them. The Pokomo have accused the government of failing to disarm the pastoralists; there have been claims that many of the cattle held by the pastoralists belonged to powerful government officials, who wished to keep those who guarded their property well-armed. On the other hand, land adjudication was perceived as mainly benefiting the farmers, and there have been strong and persistent fears among the pastoralists that together, the Pokomo, the government and foreign companies are trying to displace them from the area (Kirchner 2013). A history of arbitrary displacement of people due to dam construction and irrigation projects in the area lends credence to such fears. Local political aspirants have also played a more direct role in fueling the conflict (Kagwanja 2003). In connection to the 2013 elections, the conflict became violent again, partly because local politicians fueled ethnic tensions to gain votes; this time almost 200 people were killed (Kirchner 2013).

\section{Boundaries and local authority}

Another key driver of communal conflict, closely connected to the control over local resources as well as to electoral dynamics, concerns boundaries and local authority. As noted previously, land and the notion of "ethnic homelands" plays a crucial role in Kenyan politics. Holding land is a source of security and power for individuals, and at the group level being associated with a piece of territory provides an important component of being perceived as genuine Kenyan citizens with a legitimate claim on a stake in national power (Kurgat 2012; Lynch 2011a). The strong political salience of land and territory, together with the fact that much of the land in rural areas is communal land rather than privately owned, implies that land conflict often takes on an ethnic dimension. In many locations exact border demarcations are unclear or there are overlapping claims, and de facto settlement patterns and displacement can often affect formalizations of land claims. The question of local borders and which group has a legitimate claim to a certain territory also affects local political power and authority.

A conflict between the Garre and Murule, two Somali sub-clans, in Mandera in northeast Kenya illustrates these dynamics. The two groups, which are both traditionally pastoralist communities, have a long history of conflict and clashes over pasture and water (Menkhaus 2015). They have also been fighting about local power - which group should excert authority over Mandera district (now Mandera County). Local border demarcations were a core issue in the conflict, and became strongly politicized during Moi's rule. In 1988, administrative borders were redrawn so as to create separate political constituencies for the two clans in Mandera district, but these measures had the unintended consequence of intensifying clan-based competition and animosity, and resulted in ethnic cleansing of the respective constituencies. The redrawing of constituency borders became so strongly contested because it affected control over resources as well as electoral outcomes, and local elites used ties to the President and other national elites to acquire "their own" constituencies (Ojielo 2010). 
Aside from this form of political maneuvering, the conflict was further exacerbated by overall insecurity in the region, which borders Somalia and Ethiopia. The conflict also has cross-border dynamics, with both communities building alliances with their kin in Somalia and Ethiopia and accusing each other of harbouring foreign militants. Like other pastoralist areas Mandera has suffered from a high degree of marginalization, and there is a lingering distrust against the state, particularly the security forces, from the time of the Somali secessionist struggle in the 1960s when severe and indiscriminate force was employed (Ojielo 2010; Menkhaus 2015). The most recent waves of fighting between Garre and Murule began in 2004 (UCDP 2018). The trigger was a dispute over land, as the Garre attempted to use pasture that they had access to in the past but which now belonged to the Murule constituency. Initially isolated killings became a spiral of revenge attacks, resulting in more than 60 deaths, with many thousands fleeing the violence-affected areas. The worst single incident took place on 16 March 2005 when Murule raiders attacked El Golicha village, leaving 22 dead, with many children among the victims. This event, which gained significant news attention, prompted strong action from the government and an arbitration committee was appointed to resolve the conflict. However, the agreement that was reached mainly addressed issues of compensation and other direct outcomes of the violence, leaving the core issues unaddressed, and violence re-erupted in 2008.

\section{Addressing communal conflicts: Responses by state and non-state actors}

When lethal inter-group violence breaks out, it represents a challenge to the state's claim to have a monopoly over violence, and its ability to ensure the safety of its citizens. Consequently, even in those cases where violence was more or less instigated by the state (most notably the "ethnic clashes" under Moi), the Kenyan government has generally intervened when communal conflicts have broken out. Oftentimes, such interventions have entailed the deployment of security forces to halt violence and restore order. In turn, peace enforcement has in many cases been followed by campaigns to disarm local communities and efforts to facilitate negotiated agreements. In the case of Mandera, mentioned above, the Kibaki government appointed an arbitration committee consisting of recognized local clanand religious leaders. In other cases, broad peace conferences have been arranged to address a broader set of conflicts. For instance, a state-led peace process among pastoralist groups in northern Kenya culminated in the 2001 Modogashe Declaration which formalized an acceptance of customary conflict regulation mechanisms in addressing pastoralist conflicts (Odendaal 2013). In addition to central and local government actors, a broad range of non-state actors have also been prominent on conflict management. For instance, local community-based organizations (CBOs), non-government organizations (NGOs), and faith-based organizations have to a large extent been involved in activities such as mediation and facilitation. In many cases, several different actors - state and non-state - have been involved in responding to a specific conflict, at times working in parallel and at times actively coordinating their activities. Because the government tends to be viewed with suspicion due to the connections between communal conflict and macro politics, non-state actors are often better able to promote trust between the conflict parties and to serve in a credible mediator role. A peace process in the Kerio Valley in the early 2000s exemplifies this: After steadily escalating violent conflict over local land and cattle raiding, but also heavily influenced by local and national politics, leaders from the two groups involved - Marakwet and Pokot - began dialogue to resolve the conflict (Elfversson 2016). They turned to the Catholic Justice and Peace Commission (CJPC), a faith-based organization that had long been engaged in providing local services such as education and health care, to facilitate their negotiations. Consequently, church officials acted as mediators, with a focus on convening and facilitating meetings, until the two sides were able to reach a peace agreement known as the Kolowa 
Declaration. Government representatives were present at the Declaration and endorsed the agreement, with local government officials playing a key role in its implementation.

One outcome of the Kerio Valley peace process was the establishment of local bodies to regulate and manage minor disputes and prevent their escalation into violent conflict. Such District Peace Committees (DPCs) are of high relevance throughout conflict-affected regions of Kenya. DPCs, which can be described as hybrid bodies (encompassing both formal and informal structures), have played a major role in many local peace processes. These conflict management bodies have been of growing importance in Kenya since the 1990s, drawing upon the success of such a body in addressing longstanding conflict in Wajir in northeast Kenya. District Peace Committees are hybrid bodies that incorporate local customary conflict resolution while also drawing on formal structures and connecting to government institutions (Odendaal 2013). Membership of the peace committees is made up of locally elected elders as well as women, youth, civil society organizations and government representatives. Their main purpose is to resolve conflicts and promote peace among the different communities in a district and its neighbouring area. In 2001, a National Steering Committee (NSC) was established to coordinate the work of DPCs and other peace building bodies in Kenya and link these formally with government and development activities (Odendaal 2013). This move effectively formalized the role of DPCs, granting them additional power and legitimacy by way of having official authority; at the same time, in some cases their customary legitimacy has been eroded by their formalization. Furthermore, many have criticized the official recognition of bodies and mechanisms that encompass customary practices such as blood compensation, and oftentimes the de facto exclusion of women from formal negotiations.

\section{Devolution: Diffusing macro-conflict but intensifying local conflict?}

Since independence, the gradual centralization of power in the hands of the president has been challenged by opposition movements and civil society. One of the reasons has been that the very high stakes in the national political contest has helped fuel election-related communal violence. By devolving and diffusing power, it was argued, the notion that only the groups represented at the center are able to "eat" can be overcome. The struggle for constitutional reform picked up during the last years of Moi's rule, culminating in a referendum in 2005 where the final draft - which contained significantly less radical reforms than those promised during the campaign that got Kibaki and NARC elected - was defeated (Lynch 2006; Ghai 2008). However, after the intense election-related violence in 2008, and under significant international pressure, a new constitution was drafted which includes strong checks on executive power and a progressive bill of rights. The constitution was adopted in a referendum held on 4 August 2010, where 67\% voted in its favour, and promulgated later the same month. While the constitution has been acclaimed for its far-reaching and progressive content, it should be noted that implementation of many provisions have been obstructed or ignored by elites with an interest in maintaining the old order (Murunga et al. 2014).

A cornerstone of the constitutional reform was the devolution of power to 47 counties. These became operational after the 2013 elections, in which local governors and county assemblies were elected for the first time The new county governments were given significant power over fiscal resources and legislation, prompting concerns from several analysts that while devolution might diffuse the contest over national power, it also had the potential to intensify communal conflicts at the local level. Indeed, rather than resulting in "everyone's turn to eat", devolution in many cases produced locally excluded minorities (D'Arcy and Cornell 2016). From the perspective of ethnic violence, such situations were particularly concerning when local minorities were powerful at the national level or had strong crossborder networks, suggesting the capacity to mobilize for violence against the community in power at 
the local level. In line with such concerns, Lind (2018) points out that "in recent years levels of conflict have been greatest in counties with pointed majority-minority group divisions, notably Moyale, Marsabit, Mandera, Isiolo and Tana River". To prevent communal violence during the 2013 elections, the National Cohesion and Integration Commission ( $\mathrm{NCIC)} \mathrm{-} \mathrm{a} \mathrm{government} \mathrm{body} \mathrm{which} \mathrm{was} \mathrm{created}$ after the 2008 election-related violence and tasked with promoting peace and national unity - in several location promoted pre-election agreements between communities on how to distribute elected posts. Essentially, such power sharing agreements were negotiated amongst community "elders" - a term commonly encompassing leaders with a customary or moral authority as well as influential businessmen and other "big men" - together with party representatives, and then anchored within the broader community. This form of "negotiated democracy" in several locations was credited with the avoidance of violence in the 2013 elections (Mitullah 2017; Lind 2018).

In Migori County for instance, a deal was made whereby the positions as deputy governor and senator were promised to the second largest community. (Mitullah 2017) Migori is ethnically heterogenous and has experienced communal violence between Luo (the numerically largest group in the county) and Kuria. The Kuria are the second largest group numerically, and ahead of the 2013 elections feared exclusion from power and that they would not have a stake in the distribution of county resources. The Kuria elite were able to leverage their community's Presidential vote - promising to support the Luo candidate Odinga only if they were promised a seat at the table in Migori (Mitullah 2017). A similar negotiated deal was reached in Nakuru, which had been one of the hotbeds of previous waves of election-related violence between Kalenjin and Kikuyu (Elfversson and Sjögren 2018). Kikuyu are the largest community in Nakuru County, and Kalenjin the second largest. Among local and national elites, there were strong fears that the 2013 elections would cause renewed violence, and a pact was negotiated whereby the Kalenjin (or, more formally, the Kalenjin-dominated URP party) were promised the deputy governor post. The should can be seen against the backdrop of the national level deal between the Kikuyu presidential candidate Uhuru Kenyatta and his Kalenjin running mate William Ruto, and the pair also pushed strongly for the local Nakuru deal. The local and national pacts, in conjunction, played a major role in preventing communal violence in Nakuru in the 2013 and 2017 elections (Elfversson and Sjögren 2018; Mitullah 2017).

The idea of negotiated democracy, and whether it is a useful tool to overcome communal conflicts or rather serves to reinforce ethnic politics, has been a topic of intense debates in Kenyan media. While this form of agreements may diffuse intercommunal tension, they may also generate new disputes and they may be seen as disenfranchising ordinary voters. Local power sharing can also entail exclusion: in both Migori and Nakuru, there were other sizeable communities that were excluded from the negotiated electoral pacts. More broadly, cases such as Nakuru and Migori illustrate that while devolution has increased the stakes at the local level, whether or not this exacerbates communal conflict is conditional on broader political dynamics. Aside from power-sharing, local leaders do have the opportunity to improve local service provision and accountability vis-à-vis all local citizens, and have done so in some cases, which arguably can contribute to decrease the risk of communal conflict. Returning to Figure 1 above, there is not any visible support for the notion that violent communal conflicts have increased following devolution - if anything, the period since 2013 has seen a decrease both in the number of active conflicts per year and in the number of fatalities. Still, there is cause for caution, given increased tensions in some locations (Lind 2018). In Nakuru in particular, the nationallevel deal between Kalenjin and Kikuyu elite politicians has restrained local elites, but future developments in the national political dynamic may well open up for renewed election-related violence here and elsewhere in the Rift Valley (Elfversson and Sjögren 2018). 


\section{Conclusion}

This chapter has presented an overview of the patterns of communal conflict in Kenya, and highlighted key drivers. The politicized nature of ethnicity in Kenya, and the fact that elections and land tenure are closely associated with ethnic identity, have been highlighted as key factors explaining the prevalence of violent communal conflict. In addition to national political dynamics, four main drivers of conflict were discussed: electoral politics, cattle raiding, local resources, and boundaries and local authority. The chapter has also emphasized that specific dynamics are at play in different conflicts: The precise way that different conflict drivers interact is different from case to case, suggesting that actors seeking to manage and resolve conflicts need to conduct careful analysis of the conflict at hand. This also implies that although all conflicts should be seen against the background of a state and a political culture where ethnicity is strongly politicized, the impact of national-level political dynamics on communal conflicts will vary from case to case.

\section{Cross-references}

Ethnicity and Politics in Kenya (Mati, J.)

Ethno-communal Conflict in Sudan (Brosché, J.)

\section{References}

Adano WR, Dietz T, Witsenburg K, Zaal F (2012) Climate change, violent conflict and local institutions in Kenya's drylands. Journal of Peace Research 49 (1):65-80

Anderson D, Lochery E (2008) Violence and Exodus in Kenya's Rift Valley, 2008: Predictable and Preventable? Journal of Eastern African Studies 2 (2):328-343

Boone C (2011) Politically allocated land rights and the geography of electoral violence: The case of Kenya in the 1990s. Comparative Political Studies 44 (10):1311-1342

Branch B, Cheeseman N, Gardner L (eds) (2010) Our turn to eat: Politics in Kenya since 1950. Lit Verlag, Münster

Brosché J (2014) Masters of War: The Role of Elites in Sudan's Communal Conflicts. Uppsala University,

Brosché J, Elfversson E (2012) Communal conflict, civil war, and the state: Complexities, connections, and the case of Sudan. African Journal on Conflict Resolution 12 (1):33-60

Campbell DJ, Gichohi H, Mwangi A, Chege L (2000) Land use conflict in Kajiado District, Kenya. Land Use Policy 17:337-348

D'Arcy M, Cornell A (2016) Devolution and corruption in Kenya: Everyone's turn to eat? African Affairs 115 (459):246-273

de Smedt J (2009) 'No Raila, No Peace!' Big man politics and election violence at the Kibera grassroots. African Affairs 108 (433):581-598

Eaton D (2012) Revenge, ethnicity and cattle raiding in north-western Kenya. In: Witsenburg K, Zaal F (eds) Spaces of insecurity: Human agency in violent conflicts in Kenya. African Studies Centre, Leiden, pp 48-62

Elfversson E (2016) Peace from below: Governance and peacebuilding in Kerio Valley, Kenya. Journal of Modern African Studies 54 (3):469-493

Elfversson E, Sjögren A (2018) Do local power-sharing deals reduce communal conflict? The effects of 'negotiated democracy' in a devolved Kenya. Paper presented at the PRIS (Peace Research in Sweden) Biannual Conference, Lund, Sweden, 27-28 September 2018

Elischer S (2010) Political Parties, Elections and Ethnicity in Kenya. In: Branch D, Cheeseman N, Gardner L (eds) Our turn to Eat: Politics in Kenya since 1950. Lit Verlag, Münster, 
Ghai Y (2008) Devolution: restructuring the Kenyan state. Journal of Eastern African Studies 2 (2):211-226

Greiner C (2013) Guns, land, and votes: Cattle rustling and the politics of boundary (re)making in Northern Kenya. African Affairs 122 (447):216-237

Hassan M (2017) The strategic shuffle: Ethnic geography, the internal security apparatus, and elections in Kenya. American Journal of Political Science 61 (2):382-395

Höglund K (2009) Electoral violence in conflict-ridden societies: concepts, causes, and consequences. Terror Polit Violenc 21 (3):412-427

Kagwanja PM (2003) Globalizing ethnicity, localizing citizenship: Globalization, identity politics and violence in Kenya's Tana River Region. Africa Development 28 (1-2):112-152

Kimenyi MS, Ndung'u NS (2005) Sporadic ethnic violence: Why has Kenya not experienced a fullblown civil war? In: Collier P, Sambanis N (eds) Understanding Civil War: Evidence and analysis. World Bank, Washington, DC, pp 123-156

Kirchner K (2013) Conflicts and politics in the Tana Delta, Kenya: An analysis of the 2012-2013 clashes and the general and presidential elections 2013. Leiden University, Leiden

Klaus K, Mitchell MI (2015) Land grievances and the mobilization of electoral violence: Evidence from Côte d'Ivoire and Kenya. Journal of Peace Research 52 (5):622-635. doi:10.1177/0022343315580145

Klopp JM (2001) "Ethnic clashes" and winning elections: The case of Kenya's electoral despotism. Canadian Journal of African Studies 35 (3):473-517

Klopp JM, Zuern E (2007) The politics of violence in democratization: Lessons from Kenya and South Africa. Comparative Politics 39 (2):127-146

Kumssa A, Jones JF, Williams JH (2009) Conflict and human security in the North Rift and North Eastern Kenya. International Journal of Social Economics 36 (10):1008-1020

Kurgat AJ (2012) The ethnicization of territory: Identity and space among the Nandi in Turbo Division. In: Witsenburg K, Zaal F (eds) Spaces of insecurity: Human agency in violent conflicts in Kenya. African Studies Centre, Leiden, pp 20-47

Lind J (2018) Devolution, shifting centre-periphery relationships and conflict in northern Kenya. Political Geography 63:135-147

Lynch G (2006) The fruits of perception: 'ethnic politics' and the case of Kenya's constitutional referendum. African Studies 65 (2):233-270

Lynch G (2011a) I Say to You: Ethnic Politics and the Kalenjin in Kenya. University of Chicago Press, Chicago

Lynch G (2011b) The wars of who belongs where: The unstable politics of autochthony on Kenya's Mt Elgon. Ethnopolitics 10 (3-4):391-410. doi:10.1080/17449057.2011.596671

Martin P (2012) Conflict between pastoralists and farmers in Tana River District. In: Witsenburg K, Zaal F (eds) Spaces of insecurity: Human agency in violent conflicts in Kenya. African Studies Centre, Leiden, pp 167-193

Mati JM (2013) Antinomies in the struggle for the transformation of the Kenyan constitution (19902010). Journal of Contemporary African Studies 31 (2):235-254

Menkhaus K (2015) Conflict Assessment: Northern Kenya and Somaliland. Danish Demining Group Copenhagen

Mieth F (2012) In between cattle raids and peace meetings: Voices from the Kenya/Ugandan border region. In: Witsenburg K, Zaal $\mathrm{F}$ (eds) Spaces of insecurity: Human agency in violent conflicts in Kenya. African Studies Centre, Leiden, pp 63-87

Mitullah W (2017) Negotiated democracy: A double-barrelled sword. In: Njogu K, Wekesa PW (eds) Kenya's 2013 General Election: Stakes, practices and outcome.

Mkutu K (2008) Guns \& Governance in the Rift Valley: Pastoralist Conflict \& Small Arms. James Currey, Oxford

Murunga $\mathrm{G}$ (2004) The state, its reform and the question of legitimacy in Kenya. Identity, culture and politics 5 (1\&2):179-206 
Murunga G, Nasong'o SW (2007) Kenya: The struggle for democracy. Zed Books, London

Murunga G, Okello D, Sjögren A (eds) (2014) Kenya: The struggle for a new constitutional order. Zed Books; Nordiska Afrikainstitutet, London; Uppsala

Odendaal A (2013) A Crucial Link: Local Peace Committees and National Peacebuilding. United States Institute of Peace Press, Washington, D.C.

Ojielo O (2010) Dynamics and Trends of Conflict in Greater Mandera. Amani Papers. UNDP Kenya, Nairobi

Okumu W, Bukari KN, Sow P, Onyiego E (2017) The role of elite rivalry and ethnic politics in livestock raids in northern Kenya. The Journal of Modern African Studies 55 (3):479-509

Omolo K (2002) Political ethnicity in the democratisation process in Kenya. African Studies 61

(2):209-221

Omotola S (2010) Explaining electoral violence in Africa's 'new' democracies. African Journal on Conflict Resolution 10 (3):51-73

Oucho JO (2002) Undercurrents of ethnic conflicts in Kenya. African social studies series. Brill, Leiden

Schilling J, Locham R, Weinzierl T, Vivekananda J, Scheffran J (2015) The nexus of oil, conflict, and climate change vulnerability of pastoral communities in northwest Kenya. Earth System Dynamics 6 (2):703-717

Sundberg R, Eck K, Kreutz J (2012) Introducing the UCDP Non-State Conflict Dataset. Journal of Peace Research 49 (2):351-362

Sundberg R, Melander E (2013) Introducing the UCDP Georeferenced Event Dataset. Journal of Peace Research 50 (4):523-532. doi:10.1177/0022343313484347

Svensson I (2013) One God, many wars: Religious dimensions of armed conflict in the Middle East and North Africa. Civil Wars 15 (4):411-430. doi:10.1080/13698249.2013.853409

UCDP Conflict Encyclopedia (2018) Uppsala Conflict Data Program (UCDP), Uppsala University. www.ucdp.uu.se.

Waki PN (2008) Report of the Commission of Inquiry into Post-Election Violence. Government Printer, Nairobi 